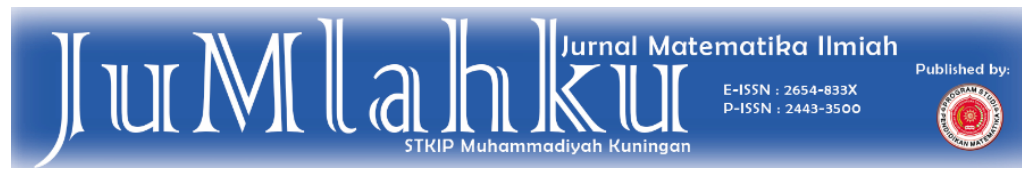

Submited: 2021-10-28

Published: 2021-11-28

\title{
Kemampuan Koneksi dan Representasi Matematis Serta Cara Pembelajaran Matematika Di SMA
}

\author{
Rustam $^{1)}$, Dona Fitriawan²), Zubaidah ${ }^{3)}$, Asep Nursangaji ${ }^{4}$ \\ 1,2,3,4Pendidikan Matematika FKIP Universitas Tanjungpura
}

Corresponding Author : donafitriawan@ @kip.untan.ac.id ${ }^{2}$

\begin{tabular}{|c|c|}
\hline Article Info & Abstract \\
\hline $\begin{array}{l}\text { Keywords :, Mathematics } \\
\text { Learning, Connection Abilit }\end{array}$ & $\begin{array}{l}\text { This study aims to determine and describe the ability of connection and } \\
\text { mathematical representation of the first choice high school students on }\end{array}$ \\
\hline Representation Ability & $\begin{array}{l}\text { the north coast. This research was conducted in a descriptive form, } \\
\text { with indirect survey stages (questionnaires and interviews) to high } \\
\text { school students about mathematical power and the way teachers } \\
\text { teach in learning mathematics. The learning carried out by the teacher } \\
\text { is examined from the approaches, methods, models, learning media in } \\
\text { mathematics. In addition, it also pays attention to how teachers solve } \\
\text { problems in learning mathematics. The implementation of research in } \\
\text { data acquisition involves students of first and second degree } \\
\text { mathematics education. Some of the students involved were given } \\
\text { briefing in advance on how to obtain data and aspects that were used } \\
\text { as studies. Some of the data collection tools used are: (1) student } \\
\text { questionnaires about the process of learning mathematics in class; (2) } \\
\text { teacher's questionnaire about the process of learning mathematics in } \\
\text { the classroom; and (3) math problems in the study of mathematical } \\
\text { power. Meanwhile, the research subjects were 10th grade science } \\
\text { students representing private and public high schools, one class each. } \\
\text { School pick-up was carried out in three north coast districts, namely } \\
\text { Sambas. So the number of schools involved in this study were six } \\
\text { schools. Meanwhile, there are six classes. The data obtained in the } \\
\text { form of student answers from the results of tests on mathematical } \\
\text { power, student interviews and teacher interviews were analyzed and } \\
\text { described. So as to obtain answers to the questions in the research. }\end{array}$ \\
\hline
\end{tabular}


Kata Kunci: Pembelajaran Matematika, Kemampuan Koneksi, Kemampuan Representasi
Penelitian ini bertujuan untuk mengetahui dan mendeskripsikan tentang kemampuan koneksi dan representasi matematis siswa SMA pilihan pertama di pantai utara. Penelitian ini dilakukan dalam bentuk deskriptif, yaitu dengan tahapan survey secara tak langsung (angket dan wawancara) terhadap siswa SMA tentang daya matematis dan cara guru mengajar dalam pembelajaran matematika. Pembelajaran yang dilakukan guru dikaji dari pendekatan, metode, model, media pembelajaran dalam matematika. Di samping itu juga memperhatikan cara guru mengatasi permasalahan dalam pembelajaran matematika. Pelaksanaan penelitian dalam perolehan data melibatkan mahasiswa pendidikan matematika strata satu maupun dua. Beberapa mahasiswa yang terlibat diberikan pembekalan terlebih dahulu tentang cara memperoleh data serta aspek yang dijadikan kajian. Beberapa alat pengumpulan data yang digunakan yaitu: (1) angket siswa tentang proses pembelajaran matematika di kelas; (2) angket guru tentang proses pembelajaran matematika di kelas; dan (3) soal matematika dalam kajian daya matematis. Sedangkan yang dijadikan subyek penelitian adalah siswa kelas 10 IPA perwakilan dari SMA Swasta dan Negeri, masing-masing satu kelas. Pengambilan sekolah dilakukan pada tiga kabupaten pantai utara, yakni Sambas. Jadi banyak sekolah yang dilibatkan dalam penelitian ini adalah enam sekolah. Sedangkan kelasnya sebanyak enam kelas. Data yang diperoleh berupa jawaban siswa dari hasil tes tentang daya matematis, hasil wawancara siswa dan hasil wawancara guru dianalisis dan dideskrpsikan. Sehingga memperoleh jawaban dari pertanyakan dalam penelitian.

\section{PENDAHULUAN}

National Council of Teacher of Mathematics (NCTM) mengemukakan bahwa kemampuan koneksi dan representasi matamatis merupakan beberapa standar proses daya matematis. Kemampuan koneksi matematis adalah hubungan antara konsep-konsep di dalam matematika itu sendiri, hubungan konsep matematika dengan bidang studi lainmaupun hubungan konsep matematika dengan kehidupan sehari-hari. Tujuan dari kemampuan koneksi matematis adalah agar peserta didik mampu berpikir krisis dan logis. Sedangkan kemampuan representasi matematis adalah salah satu kemampuan berpikir matematika yang harus dicapai peserta didik dalam upaya memperdalam pemahaman mereka tentang konsepkonsep dan menghubungkan dengan hasilnya, membandingkan dan menggunakan berbagai representasi. Representasi seperti benda-benda nyata, gambar, tabel, grafik, dan symbol yang membantu peserta didik dalam mengkomunikasikan pemikiran mereka. Melihat begitu pentingnya kemampuan 
koneksi dan representasi matematis dalam pembelajaran matematika, sehingga NCTM menetapkannya sebagai kemampuan matematika standar yang harus dikuasai oleh peserta didik (NCTM, 2019).

Studi tingkat internasional tentang perkembangan matematika dan sains oleh Trend in International Mathematics and Science Study (TIMSS) sering melakukan pengukuran terhadap kemampuan koneksi dan penalaran matematis. Ada dua domain yang diujikan dalam soal TIMSS yaitu domain konten dan domain kognitif. Domain konten matematika dalam koneksi matematis merupakan satu di antara kemampuan yang di terdapat di tujuan pembelajaran matamatika dan termuat dalam kurikulum 2006 dan juga secara tersirat dalam kurikulum 2013. Kemampuan koneksi matematis adalah kemampuan mengaitkan konsep-konsep matematika baik antar konsep matematika itu sendiri (dalam matematika) maupun mengaitkan konsep matematika dengan bidang lainnya (luar matematika), yang meliputi: koneksi antara topic matematika, koneksi dengan disiplin ilmu lain, dan koneksi dengan kehidupan sehari-hari. Oleh karena itu kemampuan koneksi matematis pada diri peserta didik hendaknya sudah ditanamkan dan dibiasakan mulai sejak dini (TIMSS, 2016).

Kemampuan koneksi matematis diperlukan peserta didik karena matematika merupakan satu kesatuan, di mana konsep yang satu berhubungan dengan konsep yang lain. Atau dengan perkataan lain untuk mempelajari suatu konsep tertentu di dalam matematika diperlukan prasyarat dari konsep-konsep yang lain. Selain itu menurut (Ruseffendi, 2006), sebagai mata pelajaran yang mempunyai fungsi sebagai lat bantu, matematika juga dapat dimanfaatkan dalam kehidupan sehari-hari serta dapat digunakan untuk melayani berbagai disiplin ilmu antara lain fisika, kimia, dan ekonomi.

Buku Prinsip dan Standar matematika Sekolah dari National Council Teacher Mathematics (NCTM) dalam (Fitriawan, 2020) dinyatakan bahwa saat peserta didik dapat menghubungkan ide-ide matematika maka pemahaman mereka akan lebih dalam dan bertahan lama.

Pemahaman peserta didik akan lebih mendalam jika mereka dapat mengaitkan antar konsep yang telah diketahui dengan konsep baru yang akan dipelajari. Seseorang akan lebih mudah mempelajari sesuatu bila belajar itu didasari kepada yang telah diketahui orang tersebut. Oleh karena itu menurut (Hudojo, 2005), untuk mempelajari suatu topic materi matematika yang baru, pengalaman belajar yang lalu dari seorang itu dapat mempengaruhi proses belajar materi matematika tersebut.

Proses pembelajaran matematika yang terjadi masih banyak yang menggunakan pendekatan pembelajaran yang kurang memperhatikan kebutuhan dan pengembangan potensi peserta didik, serta cenderung bersifat sangat teoritik. Peran pendidik masih sangat dominan (teacher centered), dan gaya mengajar yang cenderung bersifat satu arah, sehingga tidak terjadi keterlibatan peserta didik. Akhirnya, proses pembelajaran yang terjadi hanya sebatas pada penyampaian informasi saja (transfer of knowledge), kurang terkait 
dengan lingkungan sehingga peserta didik tidak mampu memahami untuk apa belajar matematika dan tidak mampu menghubungkan matematika dengan kehidupan sehari-hari. Pembelajaran yang terjadi menurut (Djamarah \& Zain, 2006), terkesan seolah-olah mengakibatkan lepasnya anak tersebut dari lingkungannya, mereka belajar sesuatu yang sama sekali tidak ada hubungannya dengan lingkungan hidupnya. Pendidikan yang terjadi hanya menekannkan pada penguasaan kelimuan berdasarkan disiplin keilmuan dan bersifat mekanistik yang menyebabkan skema anak menjadi terbelenggu sehingga dapat menurunkan daya kreativitas anak terutama ketika menghadapi masalah matematika yang terkait dengan kehidupan nyata.

Hasil penelitian yang dilakukan oleh (Aminarti et al., 2017), tentang cara pendidik mengajarkan matematika menunjukkan bahwa hanya $31,52 \%$ peserta didik menyatakan bahwa pendidik matematikanya memiliki banyak metode (variasi kegiatan) dalam pembelajaran, sisanya menyatakan guru mengajar matematika dengan cara terlalu banyak menulid dan menghafal rumus $(52,17 \%)$. Ni memprihatinkan dan menghasilkan banyaknya pendidik merasa pembelajaran matematika di kelasnya monoton dan membosankan, akibatnya pemahaman peserta didik akan materi matematika menjadi rendah.

Hal ini disebabkan karena peserta didik memandang pelajaran matematika adalah pelajaran yang sulit, tidak menyenangkan dan cenderung membosankan. Pendidik terbiasa melakukan pembelajaran dengan cara konvensional yaitu dengan menuliskan di papan tulis, menjelaskan materi seperti di buku teks, memberikan contoh soal dan memberikan tugas yang terdapat pada lembar kerja peserta didik yang hanya mengarahkanpeserta didik pada satu representasi yaitu representasi simbolik sehingga kurang mengembangkan kemmapuan komunikasi dan representasi matematis peserta didik. Padahal kemampuan komunikasi dan representasi matematis, sangat berperan dalam keberhasilan peserta didik (Puteri \& Riwayati, 2017).

Menurut (Maghfiroh \& Rohayati, 2020), representasi tersebut terkadang diajarkan atau dipelajari hanya sebagai pelengkap dalam penyelesaian masalah matematika saja. selain itu kebanyakan pendidik hanya mengajarkan representasi sejenis saja. misalnya peserta didik hanya diminta menyederhanakan pernyataan aljabar atau hanya membuat notasi matematis dari teks tertulis dengan cara penyelesaian yang diberikan oleh pendidik.

Ada tiga jenis representasi: internal, eksternal, dan bersama (shared). Representasi eksternal adalah suatu tanda, karakter, atau objek menurut Goldin dan Stheingold dalam (Atsnan et al., 2018); (Dwirahayu et al., 2020). Umumnya representasi eksternal dihasilkan oleh mahasiswa sebagai suatu produk, bukan dikonstruksi oleh mereka karena representasi eksternal telah didefiniskan dan ditetapkan. Representasi internal adalah kemampuan utnuk memahami notasi matematika yang meliputi symbolisation constructs dan assignment termasuk natural language, visual imagery, spatial 
representation,

problem-solving

strategiesand heruistics, dan affect in relation to mathematics.

Ada dua hal yang dikaji dalam pembelajaran matematikayaitu dari aspek pendidik dan peserta didik. Dari aspek pendidik yakni bagaimana cara guru mengajarkan konsep matematika meliputi metode, pendekatan, media, umpan balik, komunikasi, apersepsi, dan cara memotivasi peserta didik. Dari aspek peserta didik yakni bagaimana cara mereka memahami konsep matematika yang meliputi cara belajar dan cara mengkomunikasikan (Fitriawan et al., 2021).

Berdasarkan temuan beberapa peneliti terdahulu dan data sekunder maka peneliti tertarik untuk mengetahui dan mendeskripsikan kemampuan koneksi matematis siswa dalam mempelajari matematika, serta strategi dalam pembelajaran di kelas. Karenanya peneliti ingin mengungkapkan tentang kemampuan koneksi matematis dan representasi matematis, di samping juga mendeskripsikan cara pembelajaran guru yang dilakukan dalam kelas bagi guru matematika wajib kelas X IPA SMA .

Berdasarkan paparan pada latar belakang, berikut dirincikan rumusan masalah penelitian, yaitu: 1) Bagaimana kemampuan koneksi matematis siswa SMA pilihan pertama di wilayah pantai utara; 2) Bagaimana kemampuan representasi siswa SMA pilihan pertama di pantai utara.

\section{METODE}

Metode penelitian adalah cara ilmiah untuk mendapatkan data dengan tujuan tertentu (Sugiono, 2010). Metode penelitian yang digunakan dalam penelitian ini adalah metode penelitian deskriptif. Menurut (Nawawi, 2005), penelitian deskriptif dapat diartikan sebagai prosedur pemecahan masalah yang diselidiki dengan menggambarkan atau melukiskan keadaan subjek/objek penelitian (seseorang, lembaga, masyarakat dan lain-lain) pada saat sekarang berdasarkan fakta-fakta yang tampak atau sebagaimana adanya.

Bentuk penelitian dalam penelitian ini adalah studi kasus. Artinya, kasus yang dimaksudkan adalah kejadian terkait daya matematis siswa SMA Pilihan Pertama yang ada pada tiga kabupaten. Menurut (Nawawi, 2005), bahwa studi kasus adalah "penelitian yang memusatkan diri secara intensif terhadap objek tertentu, dengan mempelajarinya sebagai suatu kasus. Sedangkan menurut (Arikunto, 2005), studi kasus adalah suatu penelitian yang dilakukan secara intensif, terperinci dan mandalam terhadap suatu organisme, lembaga, atau gejala tertentu ditinjau dari wilayahnya, maka penelitian studi kasus hanya meliputi daerah atau subjek yang sangat sempit, tetapi ditinjau dari sifat penelitian, penelitian kasus lebih mendalam. Penelitian kasus yang diambil dari sekolah tertentu sebagai keterwaakilan kabupaten/ kota sebagai gambaran sekolah yang dianggap lebih maju dari sekolah menengah atas yang lain. Karenanya, meski dianggap 
kasus untuk sekolah tersebut, maka gambaran kemampuan terbaik sekolah pilihan pertama dalam hal tertentu dapat mewakili kabupaten yang terkait.

Dalam penelitian ini peneliti mencoba mendeskripsikan tentang daya matematis siswa dalam pembelajaran matematika kelas X IPA untuk sekolah pilihan pertama. Peneliti mengambil subjek dua sekolah pada setiap kabupaten/kota. Adapun subjek dalam penelitian ini adalah siswa kelas $X$ IPA SMA Pilihan Pertama yang telah mempelajari materi berikut: (1)eksponen dan logaritma; (2) sistem persamaan linear; (3) sistem pertidaksamaan linear; (4) matriks; (5) relasi dan fungsi; (6) barisan dan deret; (7) persamaan dan fungsi kuadrat; (8) geometri; (9) trigonstri; (10) limit dan fungsi aljabar; (11) statistika; dan (12) peluang. Karena keterbatasan peneliti, materi yang dikaji tidak secara keseluruhan tapi mengambil beberapa topik, yaitu: (1) sistem persamaan linear; (2) sistem pertidaksamaan linear; (3) relasi dan fungsi; (4) barisan dan deret; (5) persamaan dan fungsi kuadrat; (6) geometri; dan (7) trigonometri.

Adapun teknik pengumpulan data yang digunakan dalam penelitian ini sebagai berikut. 1) Teknik Tes; Teknik tes yang dimaksud pada penelitian ini adalah tes tertulis berupa soal matematika dengan topik yaitu: (1) sistem persamaan linear; (2) sistem pertidaksamaan linear; (3) relasi dan fungsi; (4) barisan dan deret; (5) persamaan dan fungsi kuadrat; (6) geometri; dan (7) trigonometri; 2) Teknik Komunikasi Langsung; Teknik komunikasi langsung pada penelitian ini adalah wawancara tidak terstruktur. Wawancara yang dilakukan adalah wawancara pada satu guru dari masing-masing sekolah, yang dapat dilakukan dengan cara wawancara tatap muka langsung atau wawancara menggunakan telepon.

Sedangkan

alat/instrumen pengumpulan data yang digunakan dalam penelitian ini sebagai berikut. 1) Tes tertulis: alat pengumpul data dalam dalam penelitian ini adalah tes tertulis yang berbentuk essay berupa soal tentang 7 topik matematika; 2) Angket siswa: yakni respon siswa yang dituangkan pada lembar yang disediakan berdasarkan pernyataan/pertanyaan yang terkait dengan proses pembelajaran matematika; 3) Angket guru: yakni respon guru yang dituangkan pada lembar yang disediakan berdasarkan pernyataan/pertanyaan yang terkait dengan proses mengajar matematika yang telah dilakukan.

Menurut Bogdan dalam (Sugiono, 2010), menyatakan "Analisis data adalah proses mencari dan menyusun secara sistematis data yang diperoleh dari hasil wawancara, catatan lapangan, dan bahanbahan lain, sehingga dapat mudah dipahami, dan temuannya dapat 
diinformasikan kepada orang lain. Dalam penelitian ini analisis data dilakukan dengan cara menganalisis jawaban tes siswa, respon angket siswa dan respon angket guru. Pengolahan data dilakukan mereduksi data, menginterpretasikan data dan menyajikan data hasil tes siswa dan angket (siswa dam guru). Mereduksi data berarti merangkum, memfokuskan pada hal-hal yang penting, dicari tema dan polanya dan membuang yang tidak perlu. Selanjutnya menyajikan data yang bertujuan memudahkan untuk memahami apa yang terjadi, merencanakan kerja selanjutnya berdasarkan apa yang telah dipahami tersebut.

\section{HASIL DAN PEMBAHASAN}

Hasil kajian penelitian yang dilakukan pada SMA Negeri 1 Sambas untuk 43 siswa, diperoleh cukup variatif dalam hal koneksi dan deskripsi matematis. Kemampuan koneksi matematis siswa sebagian besar tergambar dari jawaban yang diberikan. Ternyata dari fakta data yang diperoleh bahwa hampir $65 \%$ siswa yang memberikan jawaban yang sudah mengarah pada koneksi dan representasi yang tergolong memadai. Memperhatikan jawaban siswa tersebut, tentunya tidak dapat dipungkiri ada beberapa faktor yang mempengaruhi kondisi tersebut, yakni: 1) Faktor kesiapan dan pengalaman awal siswa; 2) Faktor guru yang mengajar, metode, pendekatan dan strategi yang digunakan, 3) Faktor materi ajar, yakni kesulitan konsep yang dipahami.
Berikut dipaparkan dalam tabel tentang kisi-kisi soal daya matematis.

Tabel 4.1. Kisi-kisi Soal Kemampuan Koneksi dan Representasi Matematis

\begin{tabular}{|c|c|c|}
\hline $\begin{array}{l}\text { Ragam } \\
\text { Daya } \\
\text { Matematis }\end{array}$ & or Indikat & o Soal \\
\hline Koneksi & \begin{tabular}{l}
\multicolumn{1}{c}{ \#Meng } \\
enali dan \\
mengaplikasi \\
kan gagasan \\
matematis ke \\
dalam \\
konteks \\
kehidupan \\
sehari-hari
\end{tabular} & $d$ \\
\hline ntasi & $\begin{array}{l}\quad \text { \# } \\
\text { Penyajian } \\
\text { matematis } \\
\text { secara visual } \\
\quad \# \\
\text { Penyajian ide } \\
\text { matematis } \\
\text { dalam simbol }\end{array}$ & $\begin{array}{l}{ }^{2} \\
a, \quad 2 b, \\
4 a, 4 b\end{array}$ \\
\hline
\end{tabular}

Berikut dipaparkan dalam tabel secara rinci perolehan nilai yang dilakukan tes pada 43 siswa.

Tabel 4.2. Rekapitulasi perolehan nilai tes kemampuan koneksi dan representasi dari setiap item.

REKAP JAWABAN SETIAP KELOMPOK

\begin{tabular}{|c|c|c|c|c|c|c|}
\hline Tingkat & \multicolumn{3}{|c|}{ Jlh } & \multirow{2}{*}{$\begin{array}{c}\text { DIm } \\
\text { Kemampuan }\end{array}$} \\
\cline { 2 - 5 } & 1a & 1b & 1c & 1d & & \\
\hline Klpk Atas Tertinggi & 10 & 10 & 10 & 9 & 39 & 98 \\
\hline Klpk Atas Terendah & 9 & 4 & 10 & 4 & 27 & 68 \\
\hline Klpk Tengah Tertingi & 9 & 9 & 9 & 0 & 27 & 68 \\
\hline Klpk Tengah Terbawah & 9 & 0 & 0 & 0 & 9 & 23 \\
\hline Klpk Bawah Tertinggi & 9 & 0 & 0 & 0 & 9 & 23 \\
\hline Klpk Bawah Terendah & 0 & 0 & 0 & 0 & 0 & 0 \\
\hline
\end{tabular}




\section{Pembahasan}

Tes Koneksi dan representasi matematis dilakukan di sekolah SMA N 1 Sambas. Tes daya matematis digunakan untuk memperoleh informasi mengenai daya matematis yang dimiliki setiap sekolah. Pembahasan yang dilakukan berdasarkan dengan tingkat kemampuan siswa dalam mengerjakan soal nomor 1 dalam koneksi dan representasi matematis sudah dirangking. Untuk itu akan dibahas hasil jawaban yang diperoleh berdasarkan tingkat kemampuan.

\section{Kelompok Atas}

Terdapat 11 siswa yang tergolong dalam kelompok atas. Namun dalam hal ini, peneliti memaparkan hasil yang diperoleh berdasarkan siswa kelompok atas dengan skor tertinggi dan siswa kelompok atas dengan skor terendah. Berikut adalah jawaban siswa dari soal nomor 1 .

\section{Tertinggi}

Siswa Kelompok Atas Dengan Skor

Soal nomor 1 pada daya matematis terdiri dari 4 bagian yaitu soal $1 \mathrm{a}, 1 \mathrm{~b}, 1 \mathrm{c}$, dan 1d. Berikut dijelaskan jawaban siswa berdasarkan bagiannya:

Analisis Data Koneksi Matematis pada Soal Nomor 1a

Soal nomor 1a dalam penelitian ini adalah koneksi matematis pada bagian representasi dengan indikator penyajian matematis secara visual. Berdasarkan hasil yang diperoleh diketahui bahwa nilai siswa R-11 adalah 10. Ini berarti bahwa siswa tersebut memahami dengan baik informasiinformasi yang terdapat dalam soal. Sehingga mampu menyajikan permasalahan dari soal tersebut secara visual. Jadi dapat disimpulkan bahwa siswa $\mathrm{R}-11$ sangat baik dalam menyajikan masalah matematis secara visual.

\section{Analisis Data Koneksi Matematis pada Soal Nomor $\mathbf{1 b}$}

Soal nomor $1 \mathrm{~b}$ dalam penelitian ini adalah daya matematis pada bagian representasi dengan indikator penyajian ide matematis dalam simbol. Berdasarkan hasil yang diperoleh diketahui bahwa nilai siswa R-11 adalah 10. Ini berarti bahwa siswa tersebut memahami dengan baik informasiinformasi yang terdapat dalam soal. Sehingga mampu menyajikan permasalahan dari soal tersebut secara simbol. Jadi dapat disimpulkan bahwa siswa R-11 sangat baik dalam menyajikan masalah matematis secara simbol.

\section{Analisis Data Representasi Matematis pada Soal Nomor 1c}

Soal nomor 1c dalam penelitian ini adalah daya matematis pada bagian komunikasi dengan indikator penyampaian ide-ide matematis secara tulisan. Berdasarkan hasil yang diperoleh diketahui bahwa nilai siswa R-11 adalah 10. Ini berarti bahwa siswa tersebut memahami dengan baik informasi-informasi yang terdapat dalam soal. Sehingga mampu memaparkan persoalan tersebut dengan sangat baik. Jadi dapat disimpulkan bahwa siswa $\mathrm{R}-11$ sangat baik dalam memberi menyampaikan ide-ide matematis secara tulisan.

\section{Analisis Data Matematis pada Soal Nomor $1 \mathrm{~d}$ \\ Representasi}

Soal nomor 1d dalam penelitian ini adalah daya matematis pada bagian koneksi dengan indikator mengenali dan mengaplikasikan gagasan matematis ke 
dalam konteks kehidupan sehari-hari. Berdasarkan hasil yang diperoleh diketahui bahwa nilai siswa R-11 adalah 9 . Dikarenakan siswa tersebut mampu mengerjakan soal nomor 1a, 1b, 1c dengan baik, sehingga juga mampu memahami dengan baik informasi-informasi yang terdapat dalam soal $2 d$. Hanya saja dari pengerjaan yang dilakukan terdapat sedikit jawaban yang membuat hasil yang diperoleh belum sepenuhnya tepat. Jadi tidak memperoleh nilai maksimal, namun dapat disimpulkan bahwa siswa R-11 sangat baik dalam menyajikan masalah matematis secara simbol.

Secara keseluruhan berdasarkan penjelasan yang telah dipaparkam mengenai daya matematis siswa $\mathrm{R}-11$ pada soal nomor 2 diperoleh skor 39 dari skor maksimal yaitu 40 , dilihat dalam persentase diperoleh $98 \%$. Jadi siswa $\mathrm{R}-11$ tergolong sangat baik dalam mengerjakan soal nomor 2 .

\section{Siswa Kelompok Atas Dengan Skor Terendah}

Soal nomor 2 pada daya matematis terdiri dari 4 bagian yaitu soal $2 a, 2 b, 2 c$, dan 2d. Berikut akan dijelaskan jawaban siswa berdasarkan bagiannya:

\section{Soal Nomor $2 a$}

Analisis Data Daya Matematis pada

Soal nomor $2 a$ dalam penelitian ini adalah daya matematis pada bagian representasi dengan indikator penyajian matematis secara visual. Berdasarkan hasil yang diperoleh diketahui bahwa nilai siswa R-8 adalah 9. Ini berarti bahwa siswa tersebut memahami dengan baik informasiinformasi yang terdapat dalam soal. Hanya saja terdapat kekurangan dalam menyajikan permasalahan dari soal tersebut secara visual. Namun secara umum dapat disimpulkan bahwa siswa R-8 sangat baik dalam menyajikan masalah matematis secara visual.

\section{Analisis Data Daya Matematis pada Soal Nomor $\mathbf{2 b}$}

Soal nomor $2 \mathrm{~b}$ dalam penelitian ini adalah daya matematis pada bagian representasi dengan indikator penyajian ide matematis dalam simbol. Berdasarkan hasil yang diperoleh diketahui bahwa nilai siswa R-8 adalah 4. Sebenarnya dilihat dari jawaban soal nomor 2a siswa R-8 mampu memahami dengan baik informasi-informasi yang terdapat dalam soal. Tetapi siswa R-8 tidak mampu menyajikan permasalahan dari soal tersebut secara simbol. Jadi dapat disimpulkan bahwa siswa R-8 sangat jelek dalam menyajikan masalah matematis secara simbol.

\section{Analisis Data Daya Matematis pada Soal Nomor 2c}

Soal nomor $2 c$ dalam penelitian ini adalah daya matematis pada bagian komunikasi dengan indikator penyampaian ide-ide matematis secara tulisan. Berdasarkan hasil yang diperoleh diketahui bahwa nilai siswa R-8 adalah 10. Ini berarti bahwa siswa tersebut memahami dengan baik informasi-informasi yang terdapat dalam soal. Sehingga mampu memaparkan persoalan tersebut dengan sangat baik. Jadi dapat disimpulkan bahwa siswa R-8 sangat baik dalam memberi menyampaikan ide-ide matematis secara tulisan.

\section{Analisis Data Daya Matematis pada Soal Nomor 2d}


Soal nomor $2 \mathrm{~d}$ dalam penelitian ini adalah daya matematis pada bagian koneksi dengan indikator mengenali dan mengaplikasikan gagasan matematis ke dalam konteks kehidupan sehari-hari. Berdasarkan hasil yang diperoleh diketahui bahwa nilai siswa $\mathrm{R}-8$ adalah 4 . Sebenarnya siswa tersebut mampu menyajikan soal dengan baik, walaupun sangat buruk dalam menyajikan soal secara simbol. Tetapi ketika diminta untuk menyelesaikan permasalahan soal pada nomor 2d, siswa tersebut menggunakan konsep matematis yang belum tepat. Jadi dapat disimpulkan bahwa siswa $\mathrm{R}-8$ sangat jelek dalam mengenali dan mengaplikasikan gagasan matematis ke dalam konteks kehidupan sehari-hari.

Secara keseluruhan berdasarkan penjelasan yang telah dipaparkam mengenai daya matematis siswa R-8 pada soal nomor 2 diperoleh skor 27 dari skor maksimal yaitu 40 , dilihat dalam persentase diperoleh $68 \%$. Jadi siswa R-8 tergolong cukup dalam mengerjakan soal nomor 2 .

\section{Kelompok Tengah}

Terdapat 19 siswa yang tergolong dalam kelompok atas. Namun dalam hal ini, peneliti memaparkan hasil yang diperoleh berdasarkan siswa kelompok tengah dengan skor tertinggi dan siswa kelompok tengah dengan skor terendah. Berikut adalah jawaban siswa dari soal nomor 2:

\section{Siswa Kelompok Tengah Dengan Skor Tertinggi}

Soal nomor 2 pada daya matematis terdiri dari 4 bagian yaitu soal 2a, 2b, 2c, dan $2 d$. Berikut akan dijelaskan jawaban siswa berdasarkan bagiannya:

\section{Analisis Data Daya Matematis pada Soal Nomor 2a}

Soal nomor $2 a$ dalam penelitian ini adalah daya matematis pada bagian representasi dengan indikator penyajian matematis secara visual. Berdasarkan hasil yang diperoleh diketahui bahwa nilai siswa R-10 adalah 9. Ini berarti bahwa siswa tersebut memahami dengan baik informasiinformasi yang terdapat dalam soal. Hanya saja terdapat kekurangan dalam menyajikan permasalahan dari soal tersebut secara visual. Namun secara umum dapat disimpulkan bahwa siswa R-10 sangat baik dalam menyajikan masalah matematis secara visual.

\section{Analisis Data Daya Matematis pada Soal Nomor $\mathbf{2 b}$}

Soal nomor $2 b$ dalam penelitian ini adalah daya matematis pada bagian representasi dengan indikator penyajian ide matematis dalam simbol. Berdasarkan hasil yang diperoleh diketahui bahwa nilai siswa R-10 adalah 9. Ini berarti bahwa siswa tersebut memahami dengan baik informasiinformasi yang terdapat dalam soal. Hanya saja terdapat kekurangan dalam menyajikan permasalahan dari soal tersebut secara simbol. Namun secara umum dapat disimpulkan bahwa siswa R-10 sangat baik dalam menyajikan masalah matematis secara simbol.

\section{Analisis Data Daya Matematis pada Soal Nomor 2c}

Soal nomor $2 \mathrm{c}$ dalam penelitian ini adalah daya matematis pada bagian komunikasi dengan indikator penyampaian ide-ide matematis secara tulisan. Berdasarkan hasil yang diperoleh diketahui 
bahwa nilai siswa R-10 adalah 9. Ini berarti bahwa siswa tersebut memahami dengan baik informasi-informasi yang terdapat dalam soal. Hanya saja terdapat kekurangan dalam memaparkan persoalan tersebut. Ini diduga karena siswa tersebut kurang lengkap dalam menyajikan persolan secara visual dan simbol. Namun secara umum dapat disimpulkan bahwa siswa R-10 sangat baik dalam menyajikan masalah matematis secara simbol.

\section{Soal Nomor 2d}

Analisis Data Daya Matematis pada

Soal nomor $2 \mathrm{~d}$ dalam penelitian ini adalah daya matematis pada bagian koneksi dengan indikator mengenali dan mengaplikasikan gagasan matematis ke dalam konteks kehidupan sehari-hari. Berdasarkan hasil yang diperoleh diketahui bahwa nilai siswa R-10 adalah 0 . Sebenarnya siswa tersebut sudah mampu mengerjakan soal nomor $2 a, 2 b, 2 c$ dengan sangat baik, walaupun tidak memperoleh nilai secara maksimal. Namun tidak mampu menyelasaikan permasalahan secara relevan dan tepat. Jadi dapat disimpulkan bahwa siswa R-10 sangat jelek dalam mengenali dan mengaplikasikan gagasan matematis ke dalam konteks kehidupan sehari-hari.

Secara keseluruhan berdasarkan penjelasan yang telah dipaparkam mengenai daya matematis siswa R-8 pada soal nomor 2 diperoleh skor 27 dari skor maksimal yaitu 40 , dilihat dalam persentase diperoleh $68 \%$. Jadi siswa R-8 tergolong cukup dalam mengerjakan soal nomor 2 .

\section{Siswa Kelompok Tengah Dengan Skor Terendah}

Soal nomor 2 pada daya matematis terdiri dari 4 bagian yaitu soal $2 \mathrm{a}, 2 \mathrm{~b}, 2 \mathrm{c}$, dan 2d. Berikut akan dijelaskan jawaban siswa berdasarkan bagiannya:

\section{Analisis Data Daya Matematis pada Soal Nomor 2a}

Soal nomor $2 a$ dalam penelitian ini adalah daya matematis pada bagian representasi dengan indikator penyajian matematis secara visual. Berdasarkan hasil yang diperoleh diketahui bahwa nilai siswa R-22 adalah 9. Ini berarti bahwa siswa tersebut memahami dengan baik informasiinformasi yang terdapat dalam soal. Hanya saja terdapat kekurangan dalam menyajikan permasalahan dari soal tersebut secara visual. Namun secara umum dapat disimpulkan bahwa siswa R-8 sangat baik dalam menyajikan masalah matematis secara visual.

\section{Analisis Data Daya Matematis pada Soal Nomor $\mathbf{2 b}$}

Soal nomor $2 b$ dalam penelitian ini adalah daya matematis pada bagian representasi dengan indikator penyajian ide matematis dalam simbol. Berdasarkan hasil yang diperoleh diketahui bahwa nilai siswa R-22 adalah 0 . Sebenarnya dilihat dari jawaban soal nomor 2a siswa R-22 mampu memahami dengan baik informasi-informasi yang terdapat dalam soal. Tetapi siswa R-22 tidak mampu menyajikan permasalahan dari soal tersebut secara simbol. Jadi dapat disimpulkan bahwa siswa R-22 sangat jelek dalam menyajikan masalah matematis secara simbol.

Analisis Data Daya Matematis pada Soal Nomor 2c 
Soal nomor $2 \mathrm{c}$ dalam penelitian ini adalah daya matematis pada bagian komunikasi dengan indikator penyampaian ide-ide matematis secara tulisan. Berdasarkan hasil yang diperoleh diketahui bahwa nilai siswa R-22 adalah 0 . Sebenarnya dilihat dari jawaban soal nomor 2a siswa R-22 mampu memahami dengan baik informasi-informasi yang terdapat dalam soal. Tetapi siswa R-22 tidak mampu memaparkan persoalan tersebut Jadi dapat disimpulkan bahwa siswa R-22 sangat jelek dalam memberi menyampaikan ide-ide matematis secara tulisan.

\section{Soal Nomor 2d}

Analisis Data Daya Matematis pada

Soal nomor $2 d$ dalam penelitian ini adalah daya matematis pada bagian koneksi dengan indikator mengenali dan mengaplikasikan gagasan matematis ke dalam konteks kehidupan sehari-hari. Berdasarkan hasil yang diperoleh diketahui bahwa nilai siswa R-22 adalah 0 . Berdasarkan soal yang sudah dikerjakan, terlihat bahwa siswa memang merasa kesulitan untuk menyelesaikan soal nomor $2 \mathrm{~b}$ dan $2 \mathrm{c}$ walaupun mampu mengerjakan soal nomor 2a. Sehingga siswa tersebut tidak mampu menggunakan konsep matematis yang tepat untuk mengerjakan soal tersebut. Jadi dapat disimpulkan bahwa siswa R-22 sangat jelek dalam mengenali dan mengaplikasikan gagasan matematis ke dalam konteks kehidupan sehari-hari.

Secara keseluruhan berdasarkan penjelasan yang telah dipaparkam mengenai daya matematis siswa R-22 pada soal nomor 2 diperoleh skor 9 dari skor maksimal yaitu 40 , dilihat dalam persentase diperoleh $23 \%$.
Jadi siswa R-8 tergolong sangat jelek dalam mengerjakan soal nomor 2 .

\section{Kelompok Rendah}

Terdapat 11 siswa yang tergolong dalam kelompok atas. Namun dalam hal ini, peneliti memaparkan hasil yang diperoleh berdasarkan siswa kelompok rendah dengan skor tertinggi dan siswa kelompok rendah dengan skor terendah. Berikut adalah jawaban siswa dari soal nomor 2:

\section{Tertinggi}

Kelompok Rendah Dengan Nilai

Soal nomor 2 pada daya matematis terdiri dari 4 bagian yaitu soal 2a, 2b, 2c, dan $2 d$. Berikut akan dijelaskan jawaban siswa berdasarkan bagiannya:

\section{Soal Nomor 2a}

Analisis Data Daya Matematis pada

Soal nomor $2 a$ dalam penelitian ini adalah daya matematis pada bagian representasi dengan indikator penyajian matematis secara visual. Berdasarkan hasil yang diperoleh diketahui bahwa nilai siswa R-25 adalah 9. Ini berarti bahwa siswa tersebut memahami dengan baik informasiinformasi yang terdapat dalam soal. Hanya saja terdapat kekurangan dalam menyajikan permasalahan dari soal tersebut secara visual. Namun secara umum dapat disimpulkan bahwa siswa R-25 sangat baik dalam menyajikan masalah matematis secara visual.

\section{Analisis Data Daya Matematis pada Soal Nomor $2 b$}

Soal nomor $2 \mathrm{~b}$ dalam penelitian ini adalah daya matematis pada bagian representasi dengan indikator penyajian ide matematis dalam simbol. Berdasarkan hasil yang diperoleh diketahui bahwa nilai siswa 
R-25 adalah 0 . Sebenarnya dilihat dari jawaban soal nomor 2a siswa R-22 mampu memahami dengan baik informasi-informasi yang terdapat dalam soal. Tetapi siswa R-22 tidak mampu menyajikan permasalahan dari soal tersebut secara simbol, ini diduga karena siswa tidak mengerti maksud soal yaitu menyajikan secara simbol dan maksud dari simbol. Jadi dapat disimpulkan bahwa siswa R-25 sangat jelek dalam menyajikan masalah matematis secara simbol.

\section{Analisis Data Daya Matematis pada Soal Nomor 2c}

Soal nomor $2 \mathrm{c}$ dalam penelitian ini adalah daya matematis pada bagian komunikasi dengan indikator penyampaian ide-ide matematis secara tulisan. Berdasarkan hasil yang diperoleh diketahui bahwa nilai siswa R-22 adalah 0 . Sebenarnya dilihat dari jawaban soal nomor 2a siswa R-22 mampu memahami dengan baik informasi-informasi yang terdapat dalam soal. Tetapi siswa R-25 juga tidak mampu memaparkan persoalan tersebut. Jadi dapat disimpulkan bahwa siswa R-22 sangat jelek dalam memberi menyampaikan ide-ide matematis secara tulisan.

\section{Analisis Data Daya Matematis pada Soal Nomor 2d}

Soal nomor $2 \mathrm{~d}$ dalam penelitian ini adalah daya matematis pada bagian koneksi dengan indikator mengenali dan mengaplikasikan gagasan matematis ke dalam konteks kehidupan sehari-hari. Berdasarkan hasil yang diperoleh diketahui bahwa nilai siswa R-25 adalah 0 . Berdasarkan soal yang sudah dikerjakan, terlihat bahwa siswa memang merasa kesulitan untuk menyelesaikan soal nomor
$2 \mathrm{~b}$ dan $2 \mathrm{c}$ walaupun mampu mengerjakan soal nomor 2a. Sehingga siswa tersebut tidak mampu menggunakan konsep matematis yang tepat untuk mengerjakan soal tersebut. Jadi dapat disimpulkan bahwa siswa R-25 sangat jelek dalam mengenali dan mengaplikasikan gagasan matematis ke dalam konteks kehidupan sehari-hari.

Secara keseluruhan berdasarkan penjelasan yang telah dipaparkam mengenai daya matematis siswa R-25 pada soal nomor 2 diperoleh skor 9 dari skor maksimal yaitu 40 , dilihat dalam persentase diperoleh $23 \%$. Jadi siswa R-8 tergolong sangat jelek dalam mengerjakan soal nomor 2 .

\section{Terendah}

Kelompok Rendah Dengan Nilai

Soal nomor 2 pada daya matematis terdiri dari 4 bagian yaitu soal 2a, 2b, 2c, dan 2d. Berikut akan dijelaskan jawaban siswa berdasarkan bagiannya:

\section{Analisis Data Daya Matematis pada Soal Nomor 2a}

Soal nomor $2 a$ dalam penelitian ini adalah daya matematis pada bagian representasi dengan indikator penyajian matematis secara visual. Berdasarkan hasil yang diperoleh diketahui bahwa nilai siswa R-43 adalah 0 . Ini berarti bahwa siswa tersebut tidak mampu memahami dengan baik informasi-informasi yang terdapat dalam soal. Jadi dapat disimpulkan bahwa siswa R43 sangat baik dalam menyajikan masalah matematis secara visual.

\section{Soal Nomor $\mathbf{2 b}$ \\ Analisis Data Daya Matematis pada}

Soal nomor $2 b$ dalam penelitian ini adalah daya matematis pada bagian representasi dengan indikator penyajian ide 
matematis dalam simbol. Berdasarkan hasil yang diperoleh diketahui bahwa nilai siswa R-43 adalah 0 . Ini berarti bahwa siswa tersebut tidak mampu memahami dengan baik informasi-informasi yang terdapat dalam soal. Sehingga tidak dapat menyajikan persoalan secara simbol. Jadi dapat disimpulkan bahwa siswa R-25 sangat jelek dalam menyajikan masalah matematis secara simbol.

\section{Analisis Data Daya Matematis pada Soal Nomor 2c}

Soal nomor $2 \mathrm{c}$ dalam penelitian ini adalah daya matematis pada bagian komunikasi dengan indikator penyampaian ide-ide matematis secara tulisan. Berdasarkan hasil yang diperoleh diketahui bahwa nilai siswa R-43 adalah 0 . Ini berarti bahwa siswa tersebut tidak mampu memahami dengan baik informasi-informasi yang terdapat dalam soal. Peniliti menduga dikarenakan siswa sudah tidak mampu menyajikan permasalahan secara visual dan simbol. Sehingga dapat dipastikan tidak dapat memaparkan persoalan tersebut. Jadi dapat disimpulkan bahwa siswa R-43 sangat jelek dalam memberi menyampaikan ide-ide matematis secara tulisan.

\section{Soal Nomor 2d}

Analisis Data Daya Matematis pada

Soal nomor $2 \mathrm{~d}$ dalam penelitian ini adalah daya matematis pada bagian koneksi dengan indikator mengenali dan mengaplikasikan gagasan matematis ke dalam konteks kehidupan sehari-hari. Berdasarkan hasil yang diperoleh diketahui bahwa nilai siswa R-43 adalah 0 . Berdasarkan soal yang sudah dikerjakan, terlihat bahwa siswa memang merasa kesulitan bahkan memperoleh nilai mom dalam menyelesaikan soal nomor $2 \mathrm{a}, 2 \mathrm{~b}$, dan 2c. Sehingga siswa tersebut dapat dipastikan tidak mampu menggunakan konsep matematis yang tepat untuk mengerjakan soal tersebut. Jadi dapat disimpulkan bahwa siswa R-43 sangat jelek dalam mengenali dan mengaplikasikan gagasan matematis ke dalam konteks kehidupan sehari-hari.

Secara keseluruhan berdasarkan penjelasan yang telah dipaparkam mengenai daya matematis siswa R-43 pada soal nomor 2 diperoleh skor 0 dari skor maksimal yaitu 40 , dilihat dalam persentase diperoleh $0 \%$. Jadi siswa R-43 tergolong sangat jelek dalam mengerjakan soal nomor 2 .

Penelitian terdahulu tentang kemampuan koneksi dan representasi matematis diperoleh sebagai berikut. 1) penelitian (Nurudini, 2019), bertujuan untuk mendeskripsikan kemampuan koneksi matematis siswa yang diperoleh kesimpulan bahwa siswa berkemampuan tinggi dapat menguasai ketiga indikator kemampuan koneksi matematis, yaitu koneksi matematis antar topik matematika, koneksi matematis dengan mata pelajaran lain, dan koneksi matematis dengan kehidupan sehari-hari. Siswa berkemampuan sedang dapat menguasai indikator I dan II. Siswa berkemampuan rendah hanya menguasai satu indikator, yaitu koneksi antar topik matematika; 2) penelitian berikutnya (Puteri \& Riwayati, 2017) bertujuan untuk apakah ada perbedaan kemampuan koneksi matematis siswa menggunakan model pembelajaran CMP dan pembelajaran konvensional yang memperoleh kesimpulan 
bahwa kemampuan koneksi matematis siswa yang diajar menggunakan model pembelajaran CMP lebih baik dibandingkan dengan pembelajaran konvensional; 3) penelitian selanjutnya (Hanifah \& Sutriyono, 2018), bertujuan untuk mendeskripsikan kemampuan representasi matematis siswa SMP pada materi geometri ditinjau dari perbedaan gender memperoleh kesimpulan bahwa siswa perempuan lebih unggul dari siswa laki-laki dalam representasi berupa pernyataan matematika atau notasi matematika, siswa perempuan lebih unggul daripada siswa laki-laki dalam representasi visual yang berupa gambar, siswa laki-laki lebih unggul daripada siswa perempuan dalam reprsentasi berupa teks tertulis/katakata.

Dari hasil penelitian, pembahasan, dan penelitian terdahulu diperoleh kesimpulan bahwa jika benar-benar diterapkan secara maksimal kemampuan koneksi dan representasi matematis akan mampu meningkatkan prestasi belajar matematika.

\section{PENUTUP}

\section{Simpulan}

Berdasarkan perolehan data, temuan hasil kajian dan paparan pada pembahasan dapat peneliti simpulkan sebagai berikut. 1) Kemampuan koneksi matematis siswa SMA pilihan pertama di wilayah pantai utara tergolong di bawah standar yang diharapkan yakni sebesar 5,3; 2) Kemampuan koneksi matematis siswa SMA pilihan pertama di wilayah pantai utara tergolong lemah karena jauh dibawah standar yakni 3,7 ; 3) Cara pembelajaran matematika di SMA pilihan pertama di wilayah pantai utara masih memerlukan banyak perbaikan.

\section{Saran}

Berdasarkan kesimpulan diperoleh saran secara pkatis bahwa masih sangat diperlukan pemahaman yang mendalam tentang kemapuan koneksi dan representasi matematis.

\section{DAFTAR PUSTAKA}

Aminarti, D., Bistari, \& Nursangaji, A. (2017). Kemampuan Pemecahan Masalah Matematika Ditinjau dari Adversity Quotient pada Materi Bangun Datar di SMP. Jurnal Pendidikan Dan Pembelajaran, 6(2), 1-12.

Arikunto, S. (2005). Prosedur Penelitian Suatu Pendekatan Praktik. Jakarta: Rineka Cipta.

Atsnan, M. F., Gazali, R. Y., \& Nareki, M. L. (2018). Pengaruh pendekatan problem solving terhadap kemampuan representasi dan literasi matematis siswa. Jurnal Riset Pendidikan Matematika, 5(2), 135-146. https://doi.org/10.21831/jrpm.v5i2.2012 0

Djamarah, \& Zain. (2006). Strategi Belajar Mengajar. Jakarta: Rineka Cipta.

Dwirahayu, G., Sandri, M., \& Kusniawati, D. (2020). Inquiry Based Rme Terhadap Kemampuan Representasi Matematik Siswa. FIBONACCI: Jurnal Pendidikan Matematika Dan Matematika, 6(1), 4558. 
https://jurnal.umj.ac.id/index.php/fbc/arti cle/view/4082

Fitriawan, D. (2020). Pengembangan Bahan Ajar Aljabar Linear Elementer Berdasarkan Kemampuan Koneksi Matematis. Jurnal Pendidikan Matematika Dan Sains, 6(1), 93-104. https://journal.uny.ac.id/index.php/jpms/ article/view/21223/pdf

Fitriawan, D., Siregar, N., Pasaribu, R. L., \& Tanjungpura, U. (2021). Problematika dalam menilai sikap peserta didik pada pembelajaran daring. 2019-2022.

Hanifah, N., \& Sutriyono. (2018). Deskripsi Kemampuan Representasi Matematis Siswa Smp Pada Materi Bangun Datar Ditinjau Dari Perbedaan Gender. Maret, 5(1), 2579-4647.

Hudojo, H. (2005). Pengembangan Kurikulum Pembelajaran Matematika. Malang: UMPress.

Maghfiroh, S., \& Rohayati, A. (2020). Analisis Kemampuan Representasi Matematis Siswa SMP Pada Materi Segiempat. Jurnal Penelitian Dan Karya IImiah, 10(1), $\quad$ 64-79. https://doi.org/10.33592/pelita.vol10.iss 1.373

Nawawi, H. (2005). Metode Penelitian Bidang Sosial. UGMPress.

NCTM. (2019). Chapter 1 Teaching Mathematics in the 21st Century. Principles and Standards for School Mathematics, 1908, 2-6.

Nurudini, N. (2019). Koneksi matematis siswa dalam menyelesaikan masalah tidak lengkap dalam diskusi kelompok. Jurnal Pendidikan, 4(2000), 1323-1332.
Puteri, W. J., \& Riwayati, S. (2017). Kemampuan Koneksi Matematis Siswa pada Model Pembelajaran Conneted Mathematics Project (CMP). Jurnal Pendidikan Matematika Dan Matematika, 3(2), 161-168.

Ruseffendi, E. T. (2006). Pengantar Kepada Membantu Guru Mengembangkan Kompetensinya Dalam Pengajaran Matematika Untuk Meningkatkan CBSA: Perkembangan kompetensi guru. Bandung: Tarsito.

Sugiono. (2010). Metode Penelitian Kuantitatif, Kualitatif, dan $R \& D$. Bandung: Alfabeta.

TIMSS. (2016). TIMSS 2015 International Results in Science. 2015. http://timssandpirls.bc.edu/timss2015/in ternational-results/ 